\title{
PENGEMBANGAN MODEL PEMBELAJARAN PROBBLEMATCH UNTUK MENINGKATKAN HASIL BELAJAR MATEMATIKA SD
}

\author{
Windarti1 ${ }^{1}$ Henny Dewi Koeswati2 ${ }^{2}$, Sri Giarti ${ }^{3}$ \\ 1Pendidikan Guru Sekolah Dasar, Universitas Kristen Satya Wacana wwindarti99@gmail.com, \\ 2Pendidikan Guru Sekolah Dasar, Universitas Kristen Satya Wacana dewi@staff.uksw.edu \\ 3Pendidikan Guru Sekolah Dasar, Universitas Kristen Satya Wacana sgiarty@gmail.com
}

\section{INFO ARTIKEL}

Riwayat Artikel:

Diterima: 20-03-2018

Disetujui: $05-04-2018$

\section{Kata Kunci:}

Probblematch, Hasil Belajar, Matematika

\section{ABSTRAK}

Abstrak: Penelitian ini bertujuan untuk mengembangkan model pembelajaran Problem Based Learning dan Hapmatch (Probblematch) untuk meningkatkan hasil belajar matematika siswa kelas 3 SD. Penelitian ini menggunakan jenis penelitian pengembangan (Reasearch \& Development). Model pengembangan yang digunakan adalah ASSURE. Penelitian ini menghasilkan media dan desain pembelajaran. Hasil uji pakar desain pembelajaran dengan persentase $76 \%$ berkategori "Sangat Tinggi", sedangkan uji validasi pakar media dengan persentase 98\% termasuk kategori "Sangat Tinggi". Kemudian hasil rata-rata Pretest dan Posttest mengalami kenaikkan dari 69 menjadi 81. Berdasarkan hasil respon guru dan siswa dapat disimpulkan bahwa model pembelajaran Probblematch yang dikembangkan pada penelitian ini layak untuk dikembangkan.

\begin{abstract}
Abstrak: This research is purposed to develop learning model of Problem Based Learning and Hapmatch in order to improve the learning result of mathematics from $3^{\text {th }}$ grade students in elementary school. This research used Research and Development model. The model is ASSURE. The result of this research are media and learning design. Expert's result of the design intructional 76\% for "very high" category, where expert validation media get $98 \%$ for "very high" category. Then, the avarage result of pretest and posttest increase from 69 to 81. Based on the result of teacher and student's respons, if can be concluded that Probblematch learning model, that is developed in this research is suitable to be developed.
\end{abstract}

\section{A. LATAR BELAKANG}

Menurut Permendiknas nomor 22 tahun 2006, Karso (2007:1.4), Hudoyo (1988:3) dalam Kristanti (2008:4-5) dan Kristanti (2008:4-5) dapat disimpulkan bahwa matematika merupakan ilmu universal yang mendasari ilmu teknologi modern, yang diatur secara logik dengan ilmu yang deduktif, akademik, formal, hirarkis, abstrak, bahasa serta simbol yang dapat digunakan untuk menyelesaikan masalah yang berkaitan dengan bilangan yang diperlukan penguasaannya sejak dini dan pembelajaran yang membuat siswa belajar serta menjadi lebih bermakna.

Menurut Purwoko, dkk (2009:62) mata pelajaran matematika yang harus diberikan untuk siswa mencakup empat kategori, yakni fakta, konsep, prinsip, dan skill (keterampilan). Berdasarkan pada pengalaman serta pangamatan yang dilakukan Purwoko, dkk (2009:62), pelajaran matematika merupakan pelajaran yang ditakuti dan disegani oleh sebagian besar siswa. Keadaan seperti ini akan sangat mempengaruhi tingkat keberhasilan siswa dalam bidang matematika. Menyikapi hal tersebut, guru selaku pendidik perlu mengupayakan cara pendekatan pembelajaran yang tepat dan sesuai dengan tingkat perkembangan siswa, serta tujuan pembelajaran matematika sehingga minat belajar siswa akan tumbuh, dan dapat mencapai prestasi yang diharapkan.
Mulyana (2014:1-2) mengungkapkan bahwa tujuan pembelajaran matematika dalam standar isi (badan standar nasional pendidikan, 2006:146) dan standar pembelajaran matematika dari NCTM (2000:29), salah satu tujuan matematika yang harus dikuasai dan dikembangkan merupakan kemampuan koneksi matematis atau kemampuan berpikir tingkat tinggi.

Purwoko dkk (2009: 1) berpendapat bahwa Tuntutan kurikulum 2006 dan era global dalam kegiatan pembelajaran matematika diantaranya menumbuh kembangkan kemampuan pemecahan masalah, melatih berpikir dan bernalar dalam menarik kesimpulan, mengembangkan kreativitas yang bisa mengikut sertakan imajinasi, intuisi dan penemuan melalui pemikiran divergen, orisinal, membuat prediksi, dan mencoba-coba (trial and error). Rosyidi dan Febrian (2013:5-11) menyatakan salah satu tujuan pembelajaran matematika di Indonesia yaitu penggunakan penalaran. Seiring dengan perkembangan IT dalam dunia pendidikan maka dalam proses pembelajaran dapat dikemas dengan pembelajaran yang berbasis ICT. Inovasi penggunaan ICT dalam pembelajaran dapat membantu siswa dalam memahami materi yang sedang diajarkan, karena ICT dapat menampilkan gambar, suara, video atau bentuk lain yang lebih nyata dari suaru objek yang akan diajarkan. 
Berdasarkan tujuan pembelajaran matematika dan kompetensi guru untuk menggunakan media ICT (TIK) dari Mendiknas nomor 16 tahun 2007, Gatot Muhsetyo, dkk (2007:27) dan Eri Murti (2013:1) dapat disimpulkan bahwa untuk pembelajaran matematika, guru harus merancang pembelajaran yang sesuai dengan media ICT (TIK). Sehingga pengunaan media pembelajaran dapat menarik siswa didalam pembelajaran matematika di kelas. Oleh karena itu guru diharuskan menggunakan media pembelajaran dalam setiap pembelajaran di dalam kelas lebih utamanya untuk pembelajaran matematika. Selain untuk meningkatkan hasil belajar siswa juga untuk membuat pembelajaran lebih menarik bagi siswa.

Namun pada kenyataannya masih banyak guru yang belum memanfaatkan ICT Ritonga dkk (2016:4) menyatakan bahwa guru masih menjadi sumber utama proses pembelajaran yang bersifat dominan. Dimana siswa hanya mendengarkan informasi yang disampaikan oleh guru dengan metode ceramah. Pembelajaran yang digunakan guru belum inovatif dan masih cenderung monoton. Ritonga dkk (2016:5) berpendapat bahwa selama ini kegiatan pembelajaran matematika masih terfokus pada bentuk mengingat dibandingkan mengkomunikasikan ide sehingga matematika menjadi salah satu pelejaran yang sulit untuk diterima dan dipahami. Seharusnya pembelajaran dilaksanakan dengan berpusat pada siswa atau dengan kata lain siswa aktif. Supaya kegiatan pembelajaran seharusnya lebih efektif apabila siswa lebih aktif. Hal ini didukung dengan Peraturan Pemerintah No 19 Tahun 2005 Ayat 1 tentang Standart Proses yang menyatakan bahwa "Satuan pendidikan diselenggarakan secara interaktif, inspiratif, menyenangkan, menantang, memotivasi siswa untuk berpartisipasi aktif serta memberikan ruang yang cukup bagi prakarsa, kreativitas, dan kemandirian sesuai bakat, minat dan perkembangan fisik dan psikologis siswa". Sehingga diharapkan siswa mampu mememuhi tujuan pendidikan yang sesuai dengan kurikulum. Penggunaan media pembelajaran interaktif yang berbasis TIK juga masih jarang digunakan oleh guru. Menurut Tirtian (2013:16) pemakaian media pembelajaran berbasis ICT dalam proses pembelajaran dapat membangkitkan keinginan dan minat yang baru, membangkitkan motivasi dan rangsangan kegiatan belajar, dan bahkan membawa pengaruh - pengaruh psikologis terhadap siswa.

Berdasarkan hasil wawancara dan pengamatan yang dilakukan di SDN Madyogondo 02 Desa Madyogondo Kecamatan Ngablak Kabupaten Magelang kelas 3 pada bulan Juni 2016, menemukan permasalahan yang berhubungan dengan pembelajaran matematika, yakni hasil bahwa siswa mengalami kesulitan di pembelajaran matematika. Hal tersebut disebabkan karena dalam mengajar guru masih menggunakan metode ceramah. Selain itu, guru juga belum menggunakan media pembelajaran yang berbasis ICT dalam pembelajaran di dalam kelas. Keadaan yang demikian pada proses pembelajaran di kelas yang menunjukkan masih banyak siswa yang belum aktif dan cenderung tidak memperhatikan kegiatan pembelajaran.

Kondisi akhirnya ini berdampak pada rendahnya hasil belajar matematika. Berikut penjabaran mengenai hasil belajar. Dengan KKM 65, dari 11 siswa hanya 7 siswa $(63 \%)$ yang dinyatakan tuntas. yang termasuk dalam kategori sangat baik sebanyak $18 \%$ atau setara dengan 2 peserta didik, peserta didik yang memenuhi kategori baik sebanyak $27 \%$ atau setara dengan 3 peserta didik, sebanyak $18 \%$ peserta didik sama dengan 2 peserta didik memenuhi kategori cukup dan sebanyak $37 \%$ yaitu 4 peserta didik masih memenuhi kategori kurang baik dan sangat kurang baik atau belum mencapai KKM.

Berdasarkan konsisi ideal dan permasalah yang ada maka dapat disimpulkan bahwa terjadi kesenjangan antara kondisi ideal dan kondisi di lapangan. Berpijak pada kesenjangan tersebut maka dalam pembelajaran matematika diperlukan model dan media pembelajaran yang menarik. Untuk mengurangi dan menjawab kebutuhan akan model maka dilakukan pengembangan model pembelajaran Probblematch akan mudah siswa memperoleh pengetahuannya sendiri mengingat model pembelajaran Probblematch menuntut siswa aktif dalam pembelajaran dengan penggunakan media yang disesuaikan dengan materi yang akan diajarkan kepada siswa. Sehingga pendalaman materi dengan mudah mereka dapatkan sendiri.

Model pembelajaran Probblematch merupakan sebuah model pembelajaran Problem Based Learning dan media Hapmatch berbasis ICT dengan beberapa pilihan dalam menu awal berupa soal, game, materi, petunjuk penggunaan dan hiburan. Model Pembelajaran Probblematch dibentuk menggunakan software Adobe Flash Creative Suite 3.

Kurniasih, dkk (2014:182) menyatakan salah satu model pembelajaran yang dapat digunakan adalah Problem Based Learning. Problem Based Learning merupakan model pembelajaran berdasarkan pada masalah. Menurut Trianto (2007: 68), pembelajaran berdasarkan masalah merupakan pendekatan yang efektif untuk pembelajaran proses berpikir tingkat tinggi untuk memecahkan masalah matematika. Agar dalam proses pembelajaran lebih menarik, maka metode PBL akan disertakan dengan media pembelajaran interaktif yang dibuat menggunakan software adobe flash CS3. Menurut Nasution (2013:3) Software Adobe Flash CS3 banyak digunakan untuk membuat aplikasi animasi. Flash (baik yang dulu dikeluarkan oleh Macromedia dan Adobe) banyak digunakan untuk membuat media pembelajaran. Dimana model pembelajaran Probblematch dibuat dengan menggunakan software adobe flash CS 3. Model pembelajaran Probblematch merupakan sebuah model pembelajaran Problem Based Learning dan Hapmatch Untuk Meningkatkan Hasil Belajar Matematika Siswa Kelas 3. Penelitian diharapkan mampu untuk meningktakan hasil belajar siswa. 


\section{B. METODE PENELITIAN}

Penelitian ini dilakukan dengan menggunakan penelitian dan pengembangan. Richey dan Kelin (2010) dalam Sugiyono (2015:28) menyatakan bahwa penelitian ini sekarang dinamakan Desaign and Development Research. Sebelumnya dinamakan developmental research. Desaign and Development Research adalah, "the system study of desaign, development and evaluation procsses with the aim of establishing an empirical basis for the creation of instructional and noninstructional product nd tool and new or enhanced model that govern their development". Perancangan dan penelitian pengembangan adalah kajian yang sistematis tentang bagaimana membuat rancangan suatu produk, mengembangkan/ memproduksi rancangan tersebut, dengan tujuan dapat diperoleh data yang empiris yang dapat digunakan sebagai dasar untuk membuat produk, alat-alat dan model yang dapat digunakan dalam pembelajaran atau nonpembelajaran.

Penelitian dan pengembangan ini mengacu pada langkah-langkah penelitian dan pengembangan yang diambil dari Giarti (2016: 318), yakni studi pendahuluan, desain dan pengembangan produk dan pengujian produk. Langkah-langkah penelitian dan pengembangan ini hanya sampai pada tahap ke-2, yaitu desain dan pengembangan produk. Penelitian ini dilakukan di SDN Madyogondo 02 Kecamatan Ngablak Kabupaten Magelang.

Prosedur dalam penelitian ini melalui dua tahapan yaitu: (1) studi pendahuluan dan (2) desain dan pengembangan. Pada saat studi pendahuluan akan dilakukan analisis kebutuhan menggunakan instrumen wawancara dan studi dokumen hasil belajar siswa di SD pada bulan Juni 2017. Tahap selanjutnya yaitu desain dan pengembangan dengan draft awal meliputi : 1) Memilih mata pelajaran; 2) Melakukan analisis SKL, Standart Kompetensi SK, Kompetensi Dasar KD serta membuat Indikator; 3) Membuat RPP dan Silabus; 4) Merancang konten yang terkaitan dengan model media; 5) Merancang media; 6) Membuka aplikasi adobe flash CS; 7) Memilih tampilan awal dalam media yang akan digunakan; 8) Membuat menu-menu yang terdapat dalam media Probblematch; 9) Memilih gambar yang akan digunakan dalam media; 10) Menambahkan animasi pada gambar dalam media; 11) Memasukkan materi dalam media; 12) Memasukkan soal dalam menu soal; 13) Menentukan skor untuk jawaban yang benar dan jawaban yang salah; 14) Membuat game yang terdapat dalam media; 15) Mendesain game agar sesuai kebutuhan siswa dan yang berkaitan dengan materi; 16) Memasukkan video dalam menu hiburan.

Setelah diperoleh draft awal Model Pembelajaran Probblematch yang telah dilengkap dengan desain pembelajaran, selanjutnya akan dilakukan uji validasi pakar. Uji validasi ini memiliki tujuan untuk dapat mengetahui kelebihan dan kelemahan model secara konseptual menurut para ahli, ketentuan teori yang akan digunakan, sehingga didapatkan kesesuaian dari isinya. Validasi ini melibatkan dua orang validator yang terdiri dari 1 orang ahli desain pembelajaran dan 1 orang ahli media pembelajaran.

Analisis data pada hasil uji coba lapangan terbatas menggunakan pengujian dengan teknik uji Man Whitney U test membandingkan hasil Pretest dan Posttest.

\section{HASIL DAN PEMBAHASAN}

1. Hasil Penelitian

Sesuai dengan model pengembangan ASSURE, langkah-langkah pembuatan model pembelajaran Probblematch, adalah sebagai berikut:

\section{a. Tahap Analyze Learners Characteristic}

Langkah pertama yang dilakukan adalah analisis kebutuhan merupakan langkah yang perlu diperhatikan untuk menentukan kemampuankemampuan atau kompetensi yang akan dipelajari oleh siswa dalam meningkatkan efektivitas dan hasil belajar. Berdasarkan hasil pengamatan yang dilakukan di SDN Madyogondo 02 Desa Madyogondo Kecamatan Ngablak Kabupaten Magelang kelas 3 pada bulan Juni 2017, menjumpai permasalahan yang berhubungan dengan pembelajaran matematika. Diperoleh hasil bahwa siswa mengalami kesulitan di pembelajaran matematika khusus dalam bidang pembagian pecahan. Guru dalam mengajar masih menggunakan metode ceramah. Guru juga belum menggunakan media pembelajaran yang dalam pembelajaran di dalam kelas. Ketika kegiatan pembelajaran berlangsung, masih banyak siswa yang belum aktif dan cenderung tidak memperhatikan kegiatan pembelajaran. Kegiatan pembelajaran yang seperti itu belum sesuai dengan tujuan pendidikan. Di dalam kurikulum mengharapkan siswa untuk berada diposisi sentral supaya kompetensi siswa dalam berbagai bidang seperti aspek kognitif, afektif, dan psikomotor mampu berkembang dan terwujud. Yang berdampak pada rendahnya hasil belajar siswa.

\section{b. Tahap State Objectives}

Langkah berikutnya adalah menyatakan standart dan tujuan belajar sespesifik mungkin. Tahap ini ditentukan standar kompetensi, kompetensi dasar, indikator dan tujuan pembelajaran yang akan dikembangkan sebagai produk dalam penelitian ini yang telah disesuaikan dengan kurikulum di SDN Madyogondo 02. Pada tahap ini standart dan tujuan pembelajaran yang akan digunakan dalam pembuatan produk yang akan dikembangkan dalam peneliti ini. Kurikulum yang digunakan dalam pengembangan model pembelajaran Probblematch adalah kurikulum KTSP. Dalam kurikulum ini terdapat Standart Kompetensi, Kompetensi Dasar dan Indikator.

Standar Kompetensi yang akan digunakan yaitu 3 . Memahami pecahan sederhana dan penggunaannya dalam pemecahan masalah, kompetensi dasar 3.1 Mengenal Pecahan Sederhana, sedangkan indikatornya yakni 1)Memahami pecahan sederhana, 2)Membandingkan pecahan sederhana, 3)Memecahkan masalah yang berkaitan dengan pecahan sederhana. Pemetaan yang dilakukan dalam analisis standar kompetensi, kompetensi dasar dan indikator menjadi dasar untuk merancang materi dan kegiatan yang ada di dalam model pembelajaran Peobblematch.

\section{c. Tahap Select Modify or Desain Method, Media Or Materials}

Pada tahap ini menentukan dan membuat media yang cocok yang berkaitan dengan masalah yang dihadapi pada pembelajaran matematika di SDN 
Madyogondo 02 Kecamatan Ngablak Kabupaten Magelang. Langkah awal pembuatan media yaitu:

1. Membuka aplikasi adobe flash CS 3

2. Memilih tampilan awal dalam media yang akan digunakan

3. Membuat menu-menu yang terdapat dalam media Hapmatch

4. Memilih gambar yang akan digunakan dalam media

5. Menambahkan animasi pada gambar dalam media

6. Memasukkan materi dalam media

7. Memasukkan soal dalam menu soal

8. Menentukan skor untuk jawaban yang benar dan jawaban yang salah

9. Membuat game yang terdapat dalam media

10. Mendesain game agar sesuai kebutuhan siswa dan yang berkaitan dengan materi

11. Memasukkan video dalam menu hiburan

\section{d. Tahap Ultilize Media And Materials}

Pada tahap ini di mana peran guru diperlukan dalam penggunaan media, teknologi dan material lain untuk membantu tercapaiannya tujuan pembelajaran. Tahap ini adalah tahap mengembangkan dan menggunakan model pembelajaran Probblematch yang cocok dalam mengatasi masalah yang dihadapi di SDN Madypgondo 02. Pada tahap ini produk mulai diimplementasian atau penggunaan produk yang dikembangkan dengan kata lain proses pembelajaran berlangsung menggunakan produk yang dihasilkan.

\section{1) Menu Awal}

Menu awal merupakan tampilan awal sebelum masuk ke dalam menu utama pada media Hapmatch. Tampilan menu awal tampak pada gambar 1 berikut.

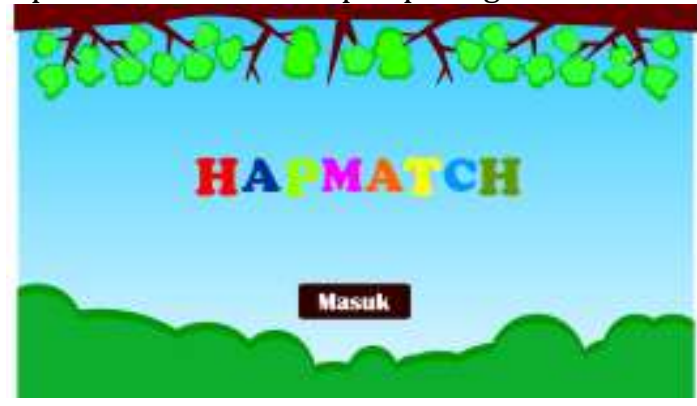

Gambar 1 Tampilan Menu Awal

\section{2) Menu Utama}

Menu utama berikan tentang Kompetensi, Materi, Soal, Game dan Hiburan. Tampilan menu utama dapat dilihat pada tabel 2 berikut.

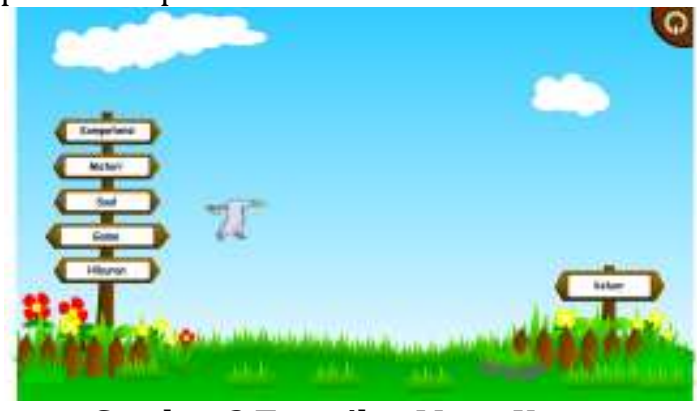

Gambar 2 Tampilan Menu Utama

\section{3) Kompetensi}

Halaman Kompetensi berisikan tentang Kompetensi Dasar yang ada di dalam media Hapmatch. Tampilan kompetensi dapat dilihat pada gambar 3 berikut.

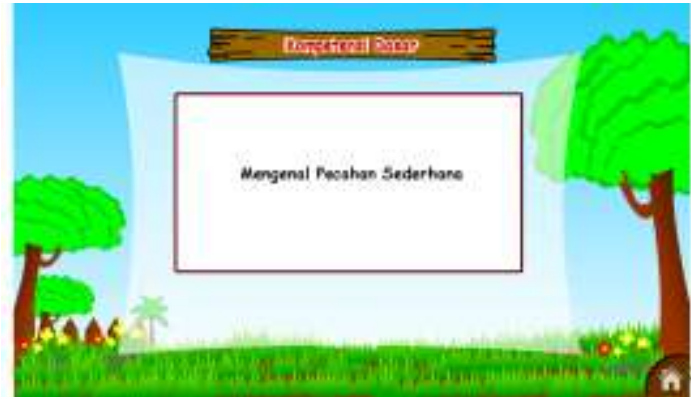

\section{4) Materi}

Gambar 3 Tampilan Kompetensi

Halaman materi berisikan tentang materi yang ada dalam media Hapmatch yang sesuai dengan soal dan game yang ada pada media. Tampilan halaman materi dapat dilihat pada gambar 4 dan 5 berikut.

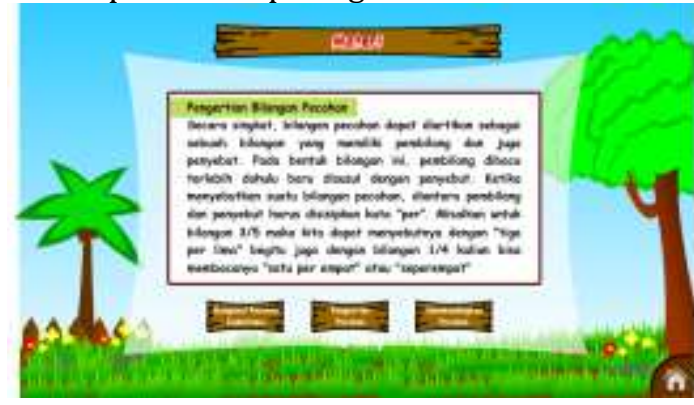

Gambar 4 Tampilan Materi

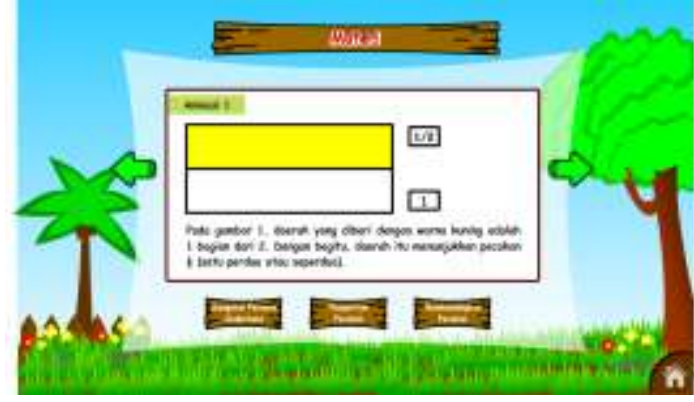

5) Soal

Gambar 5 Tampilan Materi

Halaman soal berikan tentang latihan-latihan soal yang akan dikerjakan oleh siswa. Tampilan halaman soal dapat dilihat pada gambar 6 berikut.

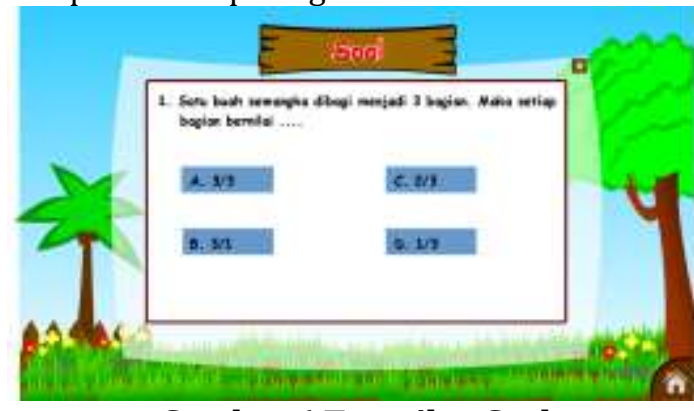

6) Game

Gambar 6 Tampilan Soal

Halaman game berisikan tentang level-level pada permainan game di media Hapmatch dan petunjuk permainan yang dapat memandu cara memainkan 
game. Tampilan halaman game dapat dilihat pada gambar 7 dan 8 berikut.

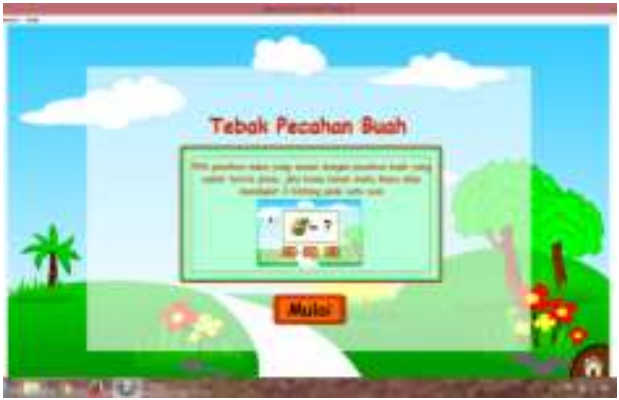

Gambar 7 Tampilan Game

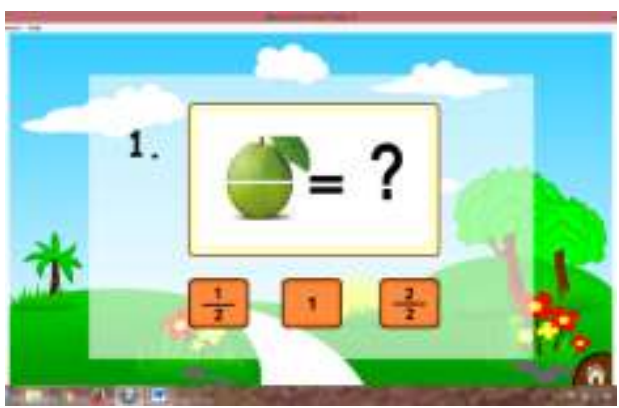

Gambar 8 Tampilan Game

\section{7) Hiburan}

Halamna hiburan berisikan beberapa video anakanak untuk menghibur siswa ketika mereka sudah selesai dengan materi, soal dan game pada media Hapmatch. Tampilan halaman hiburan dapat dilihat pada gambar 9 berikut.

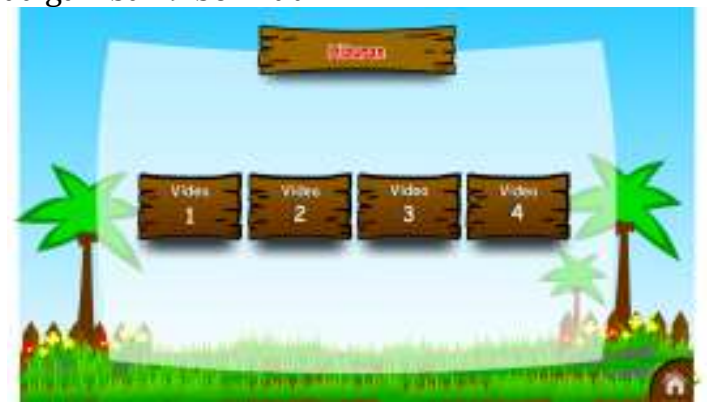

Gambar 9 Tampilan Hiburan

Pada tahap ini, selanjutnya media juga akan realisasi desain dan pengembangan dengan melakukan program pembelajaran pada media yang telah dibuat kepada responden. Pada tahap ini media Hapmatch juga akan diuji dalam dua tahap :

\section{e. Uji Pakar (expert judgement)}

Uji pakar ini merupakan tahap untuk memvalidasi media Hapmatch oleh validator. Proses validasi dilakukan dengan menggunakan instrumen yang sudah disiapkan dan disetujui oleh dosen pembimbing 1 dan dosen pembimbing 2. Validasi dilakukan oleh validator/pakar media dan valiator/pakar Desain pembelajaran. Validasi dilakukan supaya media Hapmatch yang telah dikembangkan memperoleh masukan-masukan dari validator yang ahli pada bidangnya dan sebagai bukti bahwa media ini valid untuk bisa digunakan dalam penelitian.

Setelah dilakukan tahap pengembangan materi, desain pembelajaran dan soal tes kompetensi akan dilakukan validasi. Pada tahap ini juga akan dijelaskan hasil validasi media, desain pembelajaran serta soal tes kompetensi hasil belajar siswa yang dapat dilihat pada bagian berikut ini:

\section{1) Validasi Desain Pembelajaran}

Lembar penilaian desain pembelajaran meliputi 20 butir penilaian. Berdasarkan penilaian yang dilakukan oleh validator pada aspek desain pembelajaran dengan skor presentase $76 \%$, kriteria tersebut menunjukkan bahwa desain pembelajaran termasuk dalam kategori sangat tinggi. Kesesuaian kejelasan rumusan indikator pembelajaran, kelengkapan cangkupan rumusan indikator pembelajaran, kesesuaian indikator dengan kompetensi dasar diperoleh dengan skor 3. Kesesuaian materi dengan indikator pembelajaran, kesesuaian materi dengan karakteristik siswa, keruntutan dan sistematika materi, kesesuaian materi dengan alokasi waktu dapat diperoleh skor 3. Kesesuaian sumber belajar/media dengan indikator pembelajaran, kesesuaian sumber belajar/media dengan materi pembelajaran, kesesuaian sumber belajar/media dengan karakteristik siswa memperoleh skor 3 . Kesuaian skenario pembelajaran dengan tema pembelajaran, penggunaan langkah-langkah pendekatan scientifik dalam merancang pembelajaran, kesesuaian tujuan strategi dan metode dengan indikator pembelajaran, kesesuaian strategi dan metode pembelajaran dengan materi pembelajaran, kesesuaian strategi dan metode pembelajaran dengan karakteristik siswa, kesesuaian strategi dan metode pembelajaran dengan alokasi waktu diperoleh skor 3 . Kesesuaian teknik penilaian dengan indikator pembelajaran, kesesuaian item soal dengan indikator pembelajaran, kejelasan prosedur penilaian, merancang kegiatan remidial atau pengayaan didapat skor 3. Sistematika isi secara keseluruhan ditunjukkan dengan skor 3 .

\section{2) Validasi Media}

Lembar penilaian media meliputi 10 butir penilaian. Berdasarkan hasil yang diperoleh dari validator pada aspek media dengan skor presentase 98\%, menurut kriteria menunjukkan kategori sangat tinggi. Media Hapmatch menarik dan merangsang siswa untuk belajar diperoleh skor 5. Pemilihan jenis dan ukuran huruf mendukung media menjadi lebih menarik diperoleh skor 5. Kemudahan membaca teks atau tulisan diperoleh skor 5. Pemilihan animasi diperoleh skor 5. Pemillihan warna diperoleh skor 4. Kejelasan petunjuk media diperoleh skor 5 . Kemudahan dalam pemakaian diperoleh skor 5. Kejelasan gambar, animasi maupun ilustrasi diperoleh skor 5. Kemampuan media untuk menambah pemahaman siswa diperoleh skor 5 dan kemampuan media menambah keterampilan siswa diperoleh skor 5 .

\section{f. Tahap Require Learners Participation}

Setelah media dibuat siswa dilibatkan untuk ikut berperan dalam penggunaan produk yang dikembangkan karena produk tersebut adalah model dan media pembelajaran interaktif yang memerlukan keterlibatan siswa dalam pengoperasiannya. Dan 
dilakukan uji validasi soal untuk mengetahui tingkat kevalidan dari soal tes dengan melibatkan siswa.

\section{1) Validasi Soal}

Sebelum soal tes digunakana untuk mengambil data, terlebih dahulu soal tes kompetensi hasil belajar tersebut akan dilakukan uji coba untuk mengetahui tingkan Validasi dan Realibilitas datanya. Uji coba instrumen tes dilakukan dengan 14 siswa kelas 3 SDN Magersari Kecamatan Ngablak Kabupten Magelang merupakan salah satu SD di Ngablak dan SD tersebut bukan merupakan sampel dari penelitian. Uji validasi digunakan untuk dapat mengetahui apakah konstruk butir soal pada instrumen tes (baik pretest maupun posttest) baik atau tidak untuk digunakan. Sedangakan, uji realibilitas digunakan untuk mengetahui apakah dengan alat ukur tersebut dapat menghasilkan sebuah data yang tetap dan dapat dipercaya. Kompetensi validasi dan realibilitas instrumen soal tes menggunakan bantuan program SPSS for Windows ver.20.

\section{2) Validasi Soal Pretest}

Hasil pengujian tehadap 30 soal pretest ditemukan bahwa nilai dari realibilitas soal sebesar $\alpha$ 0,606 termasuk dalam kategori cukup. Oleh karena itu kriteria yang umum dari suatu instrumen dapat dinyatakan reabel apabila nila $\alpha$ yang diperoleh dari hasil uji realibilitas diatas $\alpha$ 0,600, maka berdasarkan hasil tersebut, instrumen soal pretest pengembangan model pembelajaran Problem Based Learning dan Media Hapmatch (Probblematch) untuk meningkatkan hasil belajar siswa kelas 3 SDN Madyogondo 02 dapat dinyatakan reabel, karena nilai realibilitas $\alpha$ $0,606>\alpha 0,600$. Berkaitan dengan uji validasi, sebuah instrumen dapat dikatakan valid apabila nilai dalam Corrected Item - Total Correlation lebih besar daripada nilai koefisien korelasi product moment minimal sebesar 0,300.

Berdasarkan kriteria di atas, dari 30 item pretest yang dapat dinyatakan valid adalah 10 item yaitu item no 4,5,6,10,12,16,17,23,27,30 karena nilai Corrected Item - Total Correlation untuk 10 item pretest $>0,300$. Terdapat 20 item yang dinyatakan tidak valid karena nilai Corrected Item - Total Correlation untuk 20 item pretest < 0,300 . Untuk item yang tidak valid kemudia kan dibuang

\section{3) Validasi Soal Posttest}

Pengujian validasi dan reliabilitas soal posttest menghasilkan data validasi dan realibilitas berikut ini. Dari 30 item posttest ditemukan bahwa nilai reliabilitas sebesar $\alpha \quad 0,727$ termasuk dalam kategori baik. Oleh karena itu kriteria yang umum dari suatu instrumen dapat dinyatakan reabel apabila nila $\alpha$ yang diperoleh dari hasil uji realibilitas diatas $\alpha 0,600$, maka berdasarkan hasil tersebut, instrumen posttest pengembangan model pembelajaran Problem Based Learning dan Media Hapmatch (Probblematch) untuk meningkatkan hasil belajar siswa kelas 3 SDN Madyogondo 02 dapat dinyatakan reabel, karena nilai dari hasil reliabilitas $\alpha 0.727>\alpha 0,600$. Hasil dari pengujian validasi item posttest, berdasarkan kriteria yang telah diutarakan di atas, dari 30 item posttest yang dapat dinyatakan valid adalah 12 item yaitu item no $4,5,6,10,12,15,16,17,21,23,25,27$, karena nilai Corrected Item - Total Correlation untuk 12 item posttest > 0,300. Terdapat 18 item yang dinyatakan tidak valid karena nilai Corrected Item - Total Correlation untuk 18 item posttest <0,300. Untuk item yang tidak valid kemudia kan dibuang.

\section{4) Uji Coba Terbatas (preliminary field testing)}

Uji coba terbatas dilakukan setelah dilakukannya validasi pakar terhadap media dan materi. Revisi pada media Hapmatch dilakukan sesuai kritik dan saran yang diberikan oleh pakar media maupun pakar materi. Uji coba terbatas dilakukan kepada 11 siswa kelas 3 SD. Uji coba terbatas ini dilakukan pada hari Jumat, 09 Maret 2018. Data yang diperoleh yaitu berupa angket respon guru, angket respon siswa dan hasil tes siswa kelas 3.

\section{g. Tahap Evaluate And Revise}

Pada langkah evaluasi ini bertujuan untuk menganalisis model pembelajarn Probblematch yang dihasilkan melalui hasil nilai pretest dan posttest. Setelah melakukan pembelajaran menggunakan model pembelajaraan maka siswa akan diberikan soal posttest untuk melihat berbeda dalam hasil belajar siswa

\section{Analisis Data Uji Coba Terbatas}

\section{a) Data Hasil Pretest dan Posttest}

Deskripsi statistik pretest dan postest menunjukkan ada kenaikan yang cukup berarti antara pretest dan postest. Pada pretest diperoleh rata-rata dengan skor hanya 69, sedangkan pada postest terdapat kenaikan rata-rata menjadi 81 . Skor pretest bergerak antara 40 sampai 80 . Skor postest bergerak antara 75 sampai 91.

Dilihat dari ukuran keragaman data, mean juga jauh lebih kecil yaitu 69 untuk pretest dan 81 untuk postest. Data tersebut menunjukkan bahwa sebaran skor postest lebih beragam dibandingkan penyebaran data pretest. distribusi data skor peserta siswa pada pretest ada $5(46 \%)$ siswa yang memperoleh skor 80 100 , ada $4(36 \%)$ siswa mendapatkan skor $60-79,2$ (18\%) siswa (18\%) mendapatkan skor antara 40 - 59. Pada postest ada 5 (46\%) siswa memperoleh skor antara 80 - 100 sedangkan 6 (54\%) siswa mendapatkan skor antara 60 - 79. Dari data tersebut ditunjukkan bahwa pencapaian kompetensi siswa 
mengalami peningkatan. Data tersebut menunjukkan bahwa ada pencapaian kompetensi test untuk siswa mengalami peningkatan. Deskripsi statistik komparasi pretest dan postest sebelum dan setelah menggunakan model pembelajaran Probblematch. Pada pretest ratarata nilai hanya 69 . Pada postest, rata-rata kompetensi test siswa naik menjadi 81.

\section{b) Analisis Hasil Pretest dan Posttest}

Seperti telah disampaikan sebelumnya pada Bab III, sebelum melakukan uji U maka terlebih dahulu dilakukan uji prasyarat analisis yakni uji normalitas data. Uji normalitas data dilakukan dengan berbantuan SPSS dengan menggunakan uji Kolmogorov-Smirnov. Berikut dipaparkan hasil uji normalitas pretest dan posttest. Dari pengujian normalitas One sample Kolmogorov-Smirnov Test diperoleh nilai Assymp. Sig (2-tailed). Menurut data tersebut, berdistribusi normal, dikarenakan nilai Assym. Sig atau nilai signifikansi 2tailed keseluruhan data $>\alpha=0,05$.

Dari data nilai yaitu data pretest dan postest penerapan model pembelajaran Probblematch dengan sampel penelitian berjumlah 11 sama-sama memiliki nilai signifikansi sebesar $\alpha 0,479$ dan $\alpha 0,433$ yang lebih besar dari pada $\alpha 0,05$. Hal ini dapat diartikan bahwa penyebaran datanya adalah normal.

Pada Tabel 5 telah dijabarkan hasil perolehan dari uji $U$ yang dilaksanakan terhadap data nilai pretest dan posttest. Uji beda dilaksanakan dengan menggunakan teknik uji U Mann Whitney dengan taraf signifikansi 5\% $(\alpha=0,050)$.

Hasil dari uji U seperti terdapat pada Tabel 5 di atas memberikan informasi besarnya nilai $U$ dan sigifikansinya. Pada tabel tersebut terlihat bahwa nilai U sebesar 30 dengan memiliki taraf signifikansi sebesar $\alpha 0,042$. Oleh karena $\alpha 0,042<\alpha=0,050$, maka dampak dari variabel independen model pembelajaran Probblematch pada variabel dependen signifikan. Artinya bahwa kompetensi hasil test dengan menggunakan Model Pembelajaran Probblematch lebih tinggi bila dilihat secara signifikan dari kompetensi sebelum menggunakan Model Pembelajaran Probblematch.

Data hasil angket respon guru yang dilakukan pada uji coba terbatas. Dari angket yang diberikan kepada guru terdiri dari 8 indikator. Rata-rata jawaban dari setiap pertanyaan diperoleh isian "YA" dari indikator 1 sampai dengan 8. Dengan demikian menurut hasil angket respon guru, guru menyatakan setuju model pembelajaran Probblematch sesuai digunakan di dalam proses pembelajaran. Pembelajaran menggunakan model pembelajaran Probblematch berbasis ICT lebih mudah, Isi model pembelajaran Probblematch berbasis ICT membantuku dalam memahami materi pelajaran, Siswa menjadi termotivasi dalam pembelajaran, Model pembelajaran Probblematch berbasis ICT memudahkan siswa dalam memahami matari, Pembelajaran menjadi aktif dan interaktif, Pembelajaran menjadi aktif dan interaktif, Pembelajaran dengan model pembelajaran Probblematch berbasis ICT meningkatkan rasa ingin tahu siswa, Hasil belajar siswa menggunakan model pembelajaran Probblematch berbasis ICT meningkat, Model pembelajaran Probblematch berbasis ICT menambah kemandirian siswa semuanya mendapat jawaban "YA"

Selain angket respon guru, juga terdapat angket respon siswa. Dari angket yang diberikan kepada siswa terdiri dari 5 indikator. Rata-rata jawaban dari setiap pertanyaan diperoleh isian "YA" dari indikator 1 sampai dengan 5. Dengan demikian menurut hasil angket respon siswa, siswa menyatakan setuju model pembelajaran Probblematch sesuai digunakan di dalam proses pembelajaran. Pembelajaran menggunakan model pembelajaran Probblematch ini membuatku semangat belajar dijawab IYA. Isi dari media Hapmatch membuatku lebih cepat memahami materi jawaban IYA. Bentuk-bentuk pada media Hapmatch ini membuatku mudah memahami materi dengan jawaban IYA. Petunjuk pada media Hapmatch mudah kupahami dengan jawaban IYA. Kegiatan pembelajaran menggunakan media Hapmatch ini membuat semakin aktif dalam belajar dengan jawban IYA.

\section{c) Hasil Uji Hipotesis}

H0: $\mu$ postest $\leq \mu$ pretest Kompetensi hasil belajar setelah menggunakan Model Pembelajaran Probblematch lebih rendah atau sama dengan sebelum menggunakan Model Pembelajaran Probblematch.

Ha: $\mu$ postest $>\mu$ pretest Kompetensi hasil belajar setelah menggunakan Model Pembelajaran Probblematch lebih tinggi dari sebelum menggunakan Model Pembelajaran Probblematch.

Dari data yang diperoleh dari hasil uji U seperti yang telah dijelaskan di atas memberikan informasi besarnya nilai $U$ dan sigifikansinya. Pada tabel tersebut terlihat bahwa nilai $U$ sebesar 30 dengan memiliki taraf signifikansi sebesar $\alpha 0,042$. Oleh karena $\alpha 0,042<\alpha=$ 0,050 , maka dampak dari variabel independen model pembelajaran Probblematch pada variabel dependen signifikan. Artinya bahwa kompetensi hasil test dengan menggunakan Model Pembelajaran Probblematch lebih tinggi bila dilihat secara signifikan dari kompetensi sebelum menggunakan Model Pembelajaran Probblematch. Signifikansi perlakukan terlihat jelas bila melihat perbandingan rata-rata nilai hasil belajar seperti penjelasan sebelumnya. Rata-rata nilai hasil belajar posttest mencapai 81 , sedangkan pada pretest mencapai 69. Dengan demikian H0 ditolak dan diterima Ha. Simpulan ini berarti bahwa kompetensi hasil belajar siswa setelah menggunakan Model Pembelajaran Probblematch lebih tinggi dari pada sebelum menggunakan Model Pembelajaran Probblematch.

\section{Pembahasan}

Hasil studi pendahaluan tentang kebutuhan model diperoleh kesenjangan yang ditemui dari sekolah yaitu bahwa siswa mengalami kesulitan di pembelajaran matematika khusus dalam bidang pembagian pecahan. Guru dalam mengajar masih menggunakan metode ceramah. Guru juga belum menggunakan media pembelajaran yang dalam pembelajaran di dalam kelas. Ketika kegiatan pembelajaran berlangsung, masih banyak 
siswa yang belum aktif dan cenderung tidak memperhatikan kegiatan pembelajaran. Kegiatan pembelajaran yang seperti itu belum sesuai dengan tujuan pendidikan. Di dalam kurikulum mengharapkan siswa untuk berada diposisi sentral supaya kompetensi siswa dalam berbagai bidang seperti aspek kognitif, afektif, dan psikomotor mampu berkembang dan terwujud.

Pembahasan pengembangan Model Pembelajaran Probblematch mengacu pada rumusan masalah, yaitu tentang bagaimana pengembangan Model Pembelajaran Probblematch untuk meningkatkan hasil belajara siswa.. Pengembangan Model Pembelajaran Probblematch melalui 6 langkah ASSURE yaitu: (1) Analisis Kebutuhan untuk Menentukan Masalah dan Solusi yang tepat serta menentukan kompetensi siswa; (2) Menentukan Standar dan Tujuan Pembelajaran; (3) memilih strategi, media, pendekatan dan materi; (4) Membuat Media; (5) Melibatakan Siswa dalam Pembelajaran dengan Media yang dikembangkan; dan (6) Evaluasi dan Revisi.

Langkah pertama yang dilakukan adalah analisis kebutuhan merupakan langkah yang perlu diperhatikan untuk menentukan kemampuan-kemampuan atau kompetensi yang akan dipelajari oleh siswa dalam meningkatkan efektivitas dan hasil belajar. Berdasarkan hasil pengamatan yang dilakukan di SDN Madyogondo 02 Desa Madyogondo Kecamatan Ngablak Kabupaten Magelang kelas 3 pada bulan Juni 2016, menjumpai permasalahan yang berhubungan dengan pembelajaran matematika. Diperoleh hasil bahwa siswa mengalami kesulitan di pembelajaran matematika khusus dalam bidang pembagian pecahan. Guru dalam mengajar masih menggunakan metode ceramah. Guru juga belum menggunakan model pembelajaran dan media yang berbasis ICT dalam pembelajaran di dalam kelas. Ketika kegiatan pembelajaran berlangsung, masih banyak siswa yang belum aktif dan cenderung tidak memperhatikan kegiatan pembelajaran.

Langkah kedua adalah menyatakan standart dan tujuan belajar sespesifik mungkin. Tahap ini ditentukan standar kompetensi, kompetensi dasar, indikator dan tujuan pembelajaran yang akan dikembangkan sebagai produk dalam penelitian ini yang telah disesuaikan dengan kurikulum. Pada tahap ini standart dan tujuan pembelajaran yang akan digunakan dalam pembuatan produk yang akan dikembangkan dalam peneliti ini. Kurikulum yang digunakan dalam pengembangan model pembelajaran Probblematch adalah kurikulum KTSP.

Langkah ketiga adalah tahap menentukan dan membuat model yang cocok yang berkaitan dengan masalah yang dihadapi pada pembelajaran matematika oleh siswa. Selanjutnya setelah produk yang dibuat selesai akan dilakukan uji validasi media dan desain pembelajaran.

Langkah keempat adalah tahap di mana peran guru diperlukan dalam penggunaan model, teknologi dan material lain untuk membantu tercapaiannya tujuan pembelajaran. Tahap ini adalah tahap mengembangkan dan menggunakan model pembelajaran Probblematch yang cocok dalam mengatasi masalah yang dihadapi. Pada tahap ini produk mulai diimplementasian atau penggunaan produk yang dikembangkan dengan kata lain proses pembelajaran berlangsung menggunakan produk yang dihasilkan. Pada tahap ini juga dilakukan uji pakar dari media, desain pembelajaran dan soal tes kompetensi. Sehingga kita dapat melihat hasil uji validasi dan merevisi apa yang perlu direvisi sebelum dilakukan uji coba terbatas.

Langkah kelima adalah model dibuat dengan siswa yang dilibatkan untuk ikut berperan dalam penggunaan produk yang dikem bangkan karena produk tersebut adalah model pembelajaran dan media interaktif yang memerlukan keterlibatan siswa dalam pengoperasiannya. Dimana siswa dalam bentuk kelompok juga terlibat dalam menggunakan produk. Siswa juga mempresentasikan hasil memecahkan masalah yang diberikan oleh guru setelah menggunakan produk dalam pembelajaran.

Terakhir, pada langkah evaluasi ini bertujuan untuk menganalisis kelayakan media yang dihasilkan melalui hasil nilai posttest. Setelah melakukan pembelajaran menggunakan model pembelajaraan maka siswa akan diberikan soal posttest untuk melihat berbeda dalam hasil belajar siswa.

Hasil dari uji U diperoleh informasi besarnya nilai U dan sigifikansinya. Pada hasil uji $U$ diperoleh nilai $U$ sebesar 30 dengan memiliki taraf signifikansi sebesar $\alpha$ 0,042 . Oleh karena $\alpha 0,042<\alpha 0,050$, maka dampak dari variabel independen model pembelajaran Probblematch pada variabel dependen signifikan. Artinya bahwa kompetensi hasil test dengan menggunakan Model Pembelajaran Probblematch lebih tinggi bila dilihat secara signifikan dari kompetensi sebelum menggunakan Model Pembelajaran Probblematch.

Temuan keefektifan pada setiap langkah pengembangan model ASSURE ini sejalan dengan pandangan Smaldino, dkk (2011:109) yang menyatakan bahwa model ASSURE merupakan salah satu model yang mampu digunakan untuk menuntun pembelajaran secara sistematis dalam merencanakan suatu proses pembelajaran secara ekfektif. Model ASSURE dalam pelaksanaannya mengkombinasikan teknologi dan media ruang kelas. Jadi dengan dilakukannya perencanaan secara sistematis dapat membantu siswa dalam memecahkan masalah dan memudahkan penyampaian materi pembelajaran. Karena dalam pembelajaran terdapat proses yang komplek dan memerlukan pendekatan secara sistematis.

Produk yang dikembangkan sudah melalui uji dan disetujui oleh validator. Hasil dari validasi ahli atau pakar media dengan persentase skor keseluruhan adalah 98\% dengan kategori sangat tinggi. Sedangkan hasil dari validasi atau pakar desain pembelajaran diperoleh presentase skor keseluruhan 76\% dengan kategori tinggi.

Hasil uji coba terbatas model pembelajaran Probblematch ini dapat dilihat pada peningkatan dari hasil pretest sebelum menggunakan model pembelajaran Probblematch dan hasil posttest sesudah menggunakan model pembelajaran Probblematch, dengan rata-rata 69 untuk pretest dan 81 untuk postest. Setelah diketahui ratarata hasil pretest dan posttest akan dilakukan perhitungan komparasi rata-rata dengan menggunakan perhitungan Gain Skor, yang diperoleh hasil sebesar 12. Berdasarkan hasil analisis data yang dilakukan pada pretest dan posttest menunjukkan model pembelajaran Probblematch yang dikembangkan dapat digunakan untuk meningkatkan hasil belajar matematika.

Berdasarkan hasil pembahasan penelitian yang dilakukan, penelitian ini mendukung penelitian yang relevan dari Samsul Yudi Prabowo dan Mochamad Cholik tentang Pengembangan Media Pembelajaran Multimedia 
Menggunakan Adobe Flash Cs3 Untuk Meningkatkan Aktivitas Belajar Siswa Pada Mapel Teknologi Mekanik (Studi Pada Siswa Kelas X Teknik Permesinan SMKN 3 Surabaya). Hasil validasi materi mencapai 91,76\% yang menyatakan media pembelajaran multimedia sangat layak untuk digunakan, hasil validasi ahli media mencapai $86,67 \%$ yang menyatakan bahwa media sangat layak digunakan untuk proses pembelajaran, dan validasi siswa mencapai $84,88 \%$ yang juga menyatakan bahwa media pembelajaran multimedia sangat layak digunakan. Nilai aktiivtas siswa untuk kelas kontrol adalah 66,36 \% dan kelas eksperimen sebesar $80 \%$, artinya adanya perbedaan aktivitas belajar siswa antara siswa kelas kontrol dan kelas eksperimen. Dari penelitian pengembangan ini adalah media pembelajaran multimedia menggunakan Adobe Flash CS3 sangat berguna, mampu meningkatkan aktivitas belajar siswa. Penelitian dari Muh. Istiqlal dkk tentang Pengembangan Media Pembelajaran Berbasis Multimedia Interaktif Menggunakan Adobe Flash CS3 Dalam Pembelajaran Matematika Standar Kompetensi Memecahkan Permasalahan Yang Berkaitan Dengan Sistem Persamaan Linear Dan Pertidaksamaan Linear Satu Variabel Pada Siswa Kelas X Penelitian ini telah berhasil mengembangkan CD pembelajaran matematika yang mempunyai kualitas Sangat Baik (SB) menurut penilaian ahli materi dan pembelajaran, ahli media, dan 32 siswa kelas X dengan skor 106,0313 dari skor maksimal 125, sedangkan persentase keidealannya 84,825 \%, sehingga layak digunakan sebagai media pembelajaran.

Penelitian lain yang sejalan dengan penelitian yang dilakukan penulis bukan hanya berkaitan dengan satu komponen saja yaitu Model Pembelajaran Probblematch. Melainkan komponen lain yaitu yang berkaitan dengan model Problem Based Learning juga perlu diperhatikan. Penelitian yang sejalan yaitu yang dilakukan oleh (Wasonowati, dkk, 2014) yang berjudul "Penerapan Model Problem Based Learning (PBL) pada Pembelajaran HukumHukum Dasar Kimia Ditinjau dari Aktivitas Dan Hasil Belajar Siswa Kelas X IPA SMA Negeri 2 Surakarta Tahun Pelajaran 2013/2014". Dalam penelitian ini dikatakan bahwa dengan menggunakan model $P B L$ mampu meningkatan aktifitas dan hasil belajar siswa. Penelitian ini juga sejalan dengan yang dilak ukan oleh (Vitasari, dkk, 2016) dengan judul "Peningkatan Keaktifan dan Hasil Belajar Matematika Melalui Model Problem Based Learning Siswa Kelas V SD Negeri 5 Kutosari”. Dalam hasil penelitian ini dikatakan bahwa model Problem Based Learning mampu meningkatkan keaktifan dan hasil belajar Matematika siswa.

\section{SIMPULAN DAN SARAN}

\section{Simpulan}

Berdasarkan hasil penelitian dan pembahasan yang telah dijabarkan melalui pada bab sebelumnya, maka didapat simpulan:

1. Produk model pembelajaran Probblematch dapat dikembangkan menggunakan desain pengembangan ASSURE (analyze learner characteristic, state objectives, select, modify, or design material, utilize media and materials, require learner participation, Evaluate).
2. Produk model pembelajaran Probblematch dapat meningkatkan hasil belajar siswa.

\section{Saran}

Berdasarkan penelitian yang sudah dilakukan, maka diberikan saran sebagai berikut.

1. Bagi Siswa

Model pembelajaran Probblematch yang dikembangkan mumudahkan siswa dalam memahami materi pecahan sederhana. Penggunaan media berbasis komputer yang dikemas sedemikian rupa dapat menambah minat dan motivasi siswa dalam belajar matematika. Dengan digunakannya model pembelajaran Probblematch siswa lebih mandiri didalam belajar dan membuat mereka lebih aktif.

2. Bagi Guru

Penggunaan model pembelajaran Probblematch menjadi salah satu pilihan bagi guru untuk memilih media dalam pembelajaran. Model pembelajaran Probblematch ini dapat membantu guru didalam proses pembelajaran. Pada proses pembelajaran guru dapat menggunakan komputer atau laptop untuk melaksanakan model pembelajaran Probblematch.

3. Bagi Sekolah

Pengembangan model pembelajaran Probblematch dapat mendukung pembelajaran berbasis komputer sehingga sekolah harus menyediakan fasilitas berupa komputer bagi siswa, misalnya dengan penganggaran lab komputer untuk sekolah.

4. Bagi Penelitin Lainnya

Selanjutnya, pengembangan model pembelajaran Probblematch sebagai model pembelajaran berbasis komputer dapat digunakan untuk materi lainnya. Pengembangan model pembelajaran masih sangat luas, kembangkanlah model pembelajaran yang lainnya dengan lebih menarik lagi untuk pembelajaran siswa.

\section{UCAPAN TERIMA KASIH}

Penulis mengucapkan terimakasih kepada Ibu Dr Henny Dewi Koeswati, S.Pd., M.Pd selaku Pembimbing 1 dan Ibu Sri Giarti, S.Pd., M.Pd selaku Pembimbing 2 yang senantiasa memberikan bimbingan, nasehat, motivasi dan tempat ngeluh tiap kesulitan ngerjain kepada penulis sehingga penelitian ini selesai dengan baik.

\section{DAFTAR PUSTAKA}

[1] A. I.G. Wardani, S. J. (2007). Pemantapan Kemampuan Profesional. Jakarta: Universitas Terbuka.

[2] Akhmad Nayazik, S. Pembelajaran Matematika Model Ideal Problem Solving Dengan Teori Pemrosesan Informasi Untuk Pembentukan PendidikanKarakter dan Pemecahan Masalah Materi Dimensi Tiga Kelas X SMA. Pythagoras. 2012.

[3] Andira Rahmawati, I. Y. implementasi model pembelajaran problem based learning untuk meningkatkan penguasaan defisiensi nutrisi tumbuhan pada mahasiswa pendidikan biologi universitas pasundan. biosfer. 2017.

[4] Cholidia Febrian, A. H. Identifikasi Penalaran Induktif Siswa Dalam Memecahkan Masalah Matematika. Kampus Ketintang Surabaya, 7-11. 2013.

[5] Gatot, M. (2007). Pembelajaran Matematika SD. Jakarta: Universitas Terbuka. 
[6] Giarti, Sri. Pengembangan Modul Pelatihan Karya Tulis Ilmiah Berbasis Andragogi Berbantuan Cms Moodle. jurnal Manajemen Pendidikan Kelola. Vol 3 No 2. 2016.

[7] Heruman. (2007). Model Pembelajaran Matematika. Bandung: PT Remaja Rosdakarya.

[8] I Gusti Lanang Agung Kartika Putra1, I. D. PENGEMBANGAN MEDIA VIDEO PEMBELAJARAN DENGAN MODEL ADDIE PADA PEMBELAJARAN BAHASA INGGRIS. Jurusan Teknologi Pendidikan. 2014.

[9] I.M.Dwi, H. K. pengaruh strategi problem based learning berbasis ICT terhadap pemahaman konsep dan kemampuan pemecahan masalah fisika. jurnal pendidikan fisika, 8-17. 2013.

[10] Kristanti, D. Upaya Meningkatkan Prestasi Belajar Matematika Materi Bangun Datar Melalui Media Tangram pada Siswa Kelas VII SMP Negeri 25 Surabaya. E-Jurnal Dinas Pendidikan Kota Surabaya. 2008.

[11] Misdalima, Z. d. Pengembangan Materi Integral untuk SMA Menggunakan Pendekatan Pendidikan Matematika Realistik Indonesia (PMRI) Di Palembang. JURNAL PENDIDIKAN MATEMATIKA, no. 1 vol 3. 2009.

[12] Muh Istiqlal, e. E. Pengembangan Media Pembelajaran Berbasis Multimedia Interaktif. Prosiding FMIPA UNY. 2011.

[13] Muhson, A. Peningkatan minat belajar dan pemahaman mahasiswa melalui penerapan problem based learning. jurnal pendidikan ekonomi. 2009.

[14] Muridono, M. strategi pembelajaran pendidikan multikultural berbasis budaya lokal. PKn Progesif. 2012.

[15] Murti, K. E. Pendidikan Abad 21 dan Implementasi pada Pembelajaran Di Sekolah Menengah Kejuruan. Widyaiswara Madya, 1. 2013.

[16] Nasution, S. H. (2013). Flash untuk Media Pembelajaran Matematika. Malang: Universitas Negeri Malang.

[17] nonoy Intan Haety, E. M. pengaruh model pembelajaran matematika knisley terhadap peningkatan kemampuan koneksi matematika siswa SMA. pendidikan matematika, 16. 2014.

[18] Nurhasanah Siregar, A. R. Pentingnya Kemampuan Komunikasi dan Penalaran Matematika pada Peserta Didik. Penerapan Iptek. 2016.

[19] Prasetyaningsih, I. Pengembangan Media Pembelajaran Berbasis Multimedia Interaktif Pada Mata Pelajaran Ekonomi. PGSD Universitas PGRI Yogyakarta. 2016.

[20] R.Rusnilawati. Pengembangan Perangkat Pembelajaran Matematika Bercirikan Ative Knowledge Dengan Pendekatan Saintifik Kelas VIII. jurnal riset pendidikan matematika, 245-258. 2016.

[21] Rachmayani, D. penerapan pembelajaran reciprocal teaching untuk meningkatkan kemampuan komunikasi matematis dan kemandirian belajar matematika siswa. jurnal pendidikan unsika. 2014.

[22] Rahim, H. M. pemanfaatan ICT sebagai media pembelajaran dan informasi pada UIN Alauddin Makassar. sulesana. 2011.

[23] Sadiman, A. S. (2014). Media Pendidikan Pengertian, Pengembangan dan Pemanfaatan. Jakarta: PT Raja Grafindo Persada.

[24] Samsul Yudi Prabowo, M. C. Pengembangan Media Pembelajaran Multimedia Menggunakan. JPTM, 7-13. 2015.

[25] Sharon E Smaldino, D. L. (2011). Instrustional Technology \& Media For Learning (Teknologi Pembelajaran dan Media untuk Belajar). Jakarta: Kencana.

[26] Sintia Yuliandari, E. W. Pengembangan Media Pembelajaran Berbasis Multimedia Interaktif Pada Mata Pelajaran Ekonomi. Unesa. 2015.

[27] Slameto. (2015). Metodelogi Penelitian \& Inovasi Pendidikan. Salatiga: Satya Wacana University Press.
[28] SUDJANA, P. D. (2005). metode statistika. bandung tarsito.

[29] Sugari, A. Pengembangan Media Pembelajaran Menggunakan Multimedia Interaktif Pada Mata Pelajaran. Jurnal Pendidikan Teknik Elektro, 261 - 266. 2014.

[30] Sugiyono, P. D. (2014). Metode Penelitian Kuantitatif Kualitatif dan R\&D. Bandung: Alfabeta.

[31] Sugiyono, P. D. (2015). Metode Penelitian dan Pengembangan. Bandung: Alfabeta.

[32] Sumantri Mulyani, N. S. (2006). Perkembangan Peserta Didik. Jakarta: Universitas Terbuka.

[33] T.D Setyaningsih, A. A. Identifikasi Tahap berpikir kritis Siswa menggunakan PBL dalam Tugas Pengajuan Masalah Matematika. Kreano, vol 5 No 2 Hal 180-187. 2014.

\section{BIODATA PENULIS}

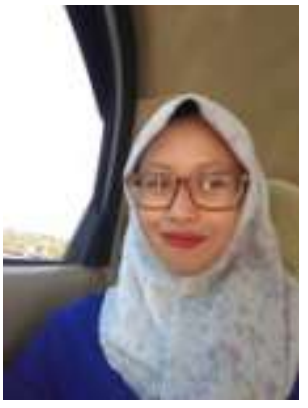

Penulis bernama lengkap "Windarti". Lahir di Dusun Gondangan Wetan 001/008 Desa Girirejo Kecamatan Ngablak Kabupaten Magelang Provinsi Jawa Tengah pada tanggal 04 Februari 1995 dari pasangan Suwardi dan Tumiyah. Penulis adalah anak kedua dari 2 bersaudara. Pendidikan sekolah dasar dimulai dari SDN Girirejo 03 Kecamatan Ngablak pada tahun 2001 2007. Setelah itu melanjutkan pendidikan sekolah menengah ke SMP Pendowo Ngablak pada tahun 2007 - 2010 dan terakhir di SMAN 1 Candimulyo pada tahun 2010 - 2013. Kemudian penulis melanjutkan studi ke perguruan tinggi di Fakultas Pertanian Progdi Agroteknologi Universitas Sebelas Maret Surakarta pada tahun 2013-2014. selanjutnya melanjutkan pendidikan di Pendidikan Guru Sekolah Dasar Universitas Kristen Satya Wacana Salatiga 2014 sampai sekarang. Kritik, saran, maupun hal-hal yang berkaitan dengan kelanjutan atau pengembangan dari hasil penelitian ini bisa dikirim ke email penulis di : wwindarti99@gmail.com 